\title{
METHODS TO USE WHEN TEACHING LEGAL ETHICS IN SOUTH AFRICA
}

\author{
E Snyman-Van Deventer \\ Bluris LLB LLM LLM LLD \\ Professor, Department of Mercantile Law \\ University of the Free State, Bloemfontein
}

\begin{abstract}
SUMMARY
Teaching legal ethics must be more than just compliance with the requirements of the legal profession but also an opportunity for every law faculty or law school to make a contribution to the development of a culture of ethics. Whether legal ethics are taught in a stand-alone module or integrated in any other module, the lecturer has to determine the goals and objectives of the module and how to achieve them and also how to assess whether the set goals and objectives have been achieved. In designing a module on legal ethics, the lecturer's own style and personality will influence the module's structure, style and technique. The lecturer therefore needs to choose the teaching method that suits him or her. Teaching methods identified include case studies, problems, Socratic instruction, discussions, group discussions, video and film presentations, cocurricular activities, lectures, the use of social media and the Internet, clinical participation, role play and simulations, law clinics, written assignments, oneminute essays, games, and moot courts. Most of these methods are not exclusive; in teaching, one most often uses a combination of the different methodologies. This article focuses mainly on the methods to be used (the "how" question) when teaching legal ethics. The objectives (the "what and why" questions) and structural aspects (the "where" questions) are also dealt with briefly. The "how" question is important because how we approach teaching needs to reflect the changing student body, the increase in student numbers and the changing learning style of our students. In answering the "how" question, various methodologies are discussed as possible ways to teach legal ethics in a South African context.
\end{abstract}




\section{$1 \quad$ INTRODUCTION $^{1}$}

In a joint press statement by the South African Law Deans Association, the Law Society of South Africa and the General Council of the Bar, it is stated that "legal practice and ethics could be viewed as capstone courses" in the final year of study. ${ }^{2}$ The statement envisages that ethics could "be taught contextually and expose students to the values of social responsiveness in legal practice". ${ }^{3}$ It also stated that "[t]he profession is currently undergoing an ethical crisis, and these fundamentals must be inculcated into prospective and candidate attorneys right from law school throughout their vocational and continuing professional development." 4 It is now eight years later and the teaching of legal ethics remains of utmost importance. ${ }^{5}$ There is still a dire need for the introduction of a legal ethics module in the South African LLB (a four-year undergraduate law degree). As most South African law schools (faculties) have been revisiting their LLB programmes as part of the South African national recurriculation project, a unique opportunity was available for law schools to ensure the inclusion of legal ethics in their LLB programmes.

In the LLB Qualification Standard, ethics and integrity are described as an applied competence for LLB students:

"The graduate has knowledge of relevant ethical considerations in law and is able to conduct her/himself ethically and with integrity in her/his relations within the university and beyond, with clients, the courts, other lawyers and members of the public."6

Teaching legal ethics should therefore be more than just compliance with the requirements of the legal profession but must also be seen as an opportunity by every law faculty or law school to make a contribution to the development of a culture of ethics. Through teaching legal ethics lecturers can assist students to

1 A first contribution on teaching legal ethics to South African law students was published as Snyman-Van Deventer and Swanepoel "Teaching the Theory and Skills of Legal Ethics to South African LLB Students" 2017 Obiter 127. This article develops the more practical aspects of teaching legal ethics with specific focus on the nine methods of teaching identified and very briefly discussed in the first article, as well as two more methods identified to assist in teaching legal ethics.

2 The South African Law Deans Association, the Law Society of South Africa and the General Council of the Bar "Joint Press Statement: Legal Education in crisis? Law Deans and the Legal Profession Set to Discuss Refinement of LLB degree" 30 January 2013. Issued by Barbara Whittle Communication Manager, Law Society of South Africa.

3 Ibid.

4 Ibid.

5 Van Zyl and Visser "Legal Ethics, Rules of Conduct and the Moral Compass: Considerations From a Law Student's Perspective" 201619 Potchefstroom Electronic Law Journal 1 13-15; Robertson and Kruuse "Legal Ethics in South Africa: Possibilities, Challenges and Opportunities" 2016 32(2) South African Journal on Human Rights 344 345-348; Kruuse "Substantive SecondLevel Reasoning and Experiental Learning in Legal Ethics" 20122 Stellenbosch Law Review $280280-284$.

6 Council on Higher Education Higher Eduation Qualifications Sub-Framework: Qualification Standard for the Bachelors of Laws (LLB) (May 2015) 1-17 15. 
find their inner ethical compass and help them make decisions accordingly. Van Zyl and Visser emphasise that a moral compass is also needed to guide the practitioner. ${ }^{7}$ Menkel-Meadow and Sander suggest that students should be equipped with a sense of individual responsibility and self-regulation and they must be able to ask moral and professional questions, and develop a sense of concern for the welfare and interest of the public. ${ }^{8}$

The first step in a process to include the teaching of legal ethics in the LLB programme is to determine the content of such a module and to decide if the teaching of legal ethics is the teaching of rules of conduct and professional responsibility only or whether it is more than just that. ${ }^{9}$ Green declares that students must be equipped as lawyers with knowledge of legal ethics and the profession's values, and be able to use this knowledge to identify and solve ethical problems or dilemmas. ${ }^{10}$ In re-curriculation, faculties in South African law schools must determine the specific aspects and knowledge of legal ethics to be taught either in the legal ethics module or integrated with the curriculum. ${ }^{11}$

The second step is to determine whether legal ethics should be taught (i) in only one module, or (ii) in a core module but also be included in other substantive modules; or (iii) throughout the entire curriculum without any specific module dedicated to legal ethics. In the (re)curriculum process, South African law schools must decide between these options. Even when choosing to teach legal ethics in a stand-alone module, legal ethics may still also be taught in other modules. Taking into account the lack of resources and teaching staff, it may be a short-term solution to include aspects of legal ethics across the curriculum.

The third step is to determine how to teach legal ethics. The lecturer needs to determine the specific methods of teaching that will best suit not only his or her own style, but that will also contribute to optimising the learning of the students.

This article focuses mainly on the methods to be used (the "how" question) when teaching legal ethics. The objectives (the "what and why" questions) and structural aspects (the "where" questions) will be dealt with very briefly. ${ }^{12}$ The "how" question is important because how we approach teaching needs to reflect the changing student body, the increase in student numbers and the changing learning style of our students. In answering the "how" question, twelve

Van Zyl and Visser 2016 PELJ 9.

8 Menkel-Meadow and Sander "Infusion Method at UCLA: Teaching Ethics Pervasively" 199558 Law and Contemporary Problems 129130.

$9 \quad$ Snyman-Van Deventer and Swanepoel 2017 Obiter 127140.

10 Green "Less is More: Teaching Legal Ethics in Context" 1998 William and Mary Law Review 367. Also see Menkel-Meadow and Sander "The 'Infusion' Method at UCLA: Teaching Ethics Pervasively" 199558 Law and Contemporary Problems 129 130; Snyman-Van Deventer and Swanepoel 2017 Obiter 140.

11 Green 1998 William and Mary Law Review 367.

12 For a discussion on the objectives and structural aspects, see Snyman-Van Deventer and Swanepoel 2017 Obiter 127-147. 
methodologies ${ }^{13}$ from the American experience and two additional methods, namely the one-minute essay and moot courts, are discussed as possible ways to teach legal ethics in a South African context. The teaching methods ${ }^{14}$ identified are case studies, ${ }^{15}$ problems, ${ }^{16}$ Socratic instruction, ${ }^{17}$ discussions, ${ }^{18}$ group discussions, video and film presentations, ${ }^{19}$ co-curricular activities, ${ }^{20}$ lectures, ${ }^{21}$ the use of social media and the Internet, clinical participation, role play and simulations, law clinics, written assignments, one-minute essays, games, and moot courts. As Kruuse said of her article published in 2012, it is hoped that this article too "will give readers food for thought, not only about the way in which law is taught at their various faculties and law schools, but also take the subject of legal ethics more seriously". ${ }^{22}$

\section{ANSWERS TO THE WHAT, WHERE, AND HOW QUESTIONS}

\section{What?}

Whether legal ethics are taught in a stand-alone module or in any other module, the onus is on the lecturer to determine: (i) all the goals and objectives of the module; (ii) how to achieve the goals and objectives; and (iii) how to assess whether the set goals and objectives have been achieved. ${ }^{23}$ In designing a module on legal ethics, the lecturer must give attention to structure, style, technique and substance to ensure that the identified outcomes, goals and objectives are met. ${ }^{24}$ According to Terrel, more emphasis should be placed on

13 Burns (in "Teaching Legal Ethics" 1993 4(1) Legal Education Review 141 151-154) identified seven methods, namely case studies, problems, Socratic instruction, discussions, video and film presentations, co-curricular activities and lectures. Those seven as well as the use of social media and role play are briefly discussed in Snyman-Van Deventer and Swanepoel 2017 Obiter 143-146.

14 Burns 1993 Legal Education Review 151-154; Snyman-Van Deventer and Swanepoel 2017 Obiter 143-146.

15 Burns 1993 Legal Education Review 151.

16 Burns 1993 Legal Education Review 152.

17 Ibid.

18 Burns 1993 Legal Education Review 153.

19 lbid.

20 Burns 1993 Legal Education Review 154.

21 Ibid.

22 Kruuse 2012 Stellenbosch Law Review 280280.

23 Burnham "Teaching Legal Ethics in Contracts" 1991 Journal of Legal Education 107; HenrissAnderssen "Teaching Legal Ethics to First Year Law Students" 2002 13(1) Legal Education Review 49; Snyman-Van Deventer and Swanepoel 2017 Obiter 139.

24 Terrell "Ethics With an Attitude: Comments on New Directions for Keck Philanthropy" 199558 Law and Contemporary Problems 355355. 
the outcomes and the lecturer should rather focus on what he or she teaches than how he or she teaches it. ${ }^{25}$

Aaronson identifies the four overlapping domains of good lawyering as role conceptualisation, problem-solving, decision-making and practical judgment. ${ }^{26}$ In designing and also teaching a legal ethics module, we can contribute to the development of all four of these domains. Brest states that law students will need to solve problems, make decisions and plan throughout their careers ${ }^{27}$ and a good lawyer must be able to "assist clients in articulating their problems, defining their interest, ordering their objectives, and generating, assessing, and implementing alternative solutions". ${ }^{28}$ To enable a student to achieve all that, a student needs multifaceted skills and therefore our teaching needs to contribute to the development of all of these skils. ${ }^{29}$

According to Green, lecturers should ensure that they equip their students as best they can to become lawyers with (i) ethical knowledge and professional values; (ii) the skill to recognise ethical problems as they arise in practice; and (iii) the ability to solve these ethical dilemmas. ${ }^{30}$ Tzannes indicates that the objectives of teaching legal ethics are (i) to teach the rules of professional conduct, (ii) to instil doctrines of ethical practice, and (iii) to enable students to identify their various responsibilities when making an ethical decision. ${ }^{31}$

In light of all these imperatives, we must ask the question: why do we want to include a module on legal ethics in our curriculum, and what do we want to teach in such a module? ${ }^{32}$

The teaching of legal ethics may be described as teaching students to understand:

(i) the legal profession, its structures, roles and responsibilities; ${ }^{33}$

(ii) the lawyer's role and responsibility when providing professional service; ${ }^{34}$

(iii) the disciplinary rules of the legal profession; ${ }^{35}$

25 Ibid.

26 Aaronson "Thinking Like a Fox: Four Overlapping Domains of Good Lawyering" 20029 Clinical Law Review 12.

27 Brest "The Responsibility of Law Schools: Educating Lawyers as Counsellors and Problem Solvers" 199558 Law and Contemporary Problems 59.

28 Ibid.

29 Ibid.

30 Green 1998 William and Mary Law Review 367. Also see Menkel-Meadow and Sander 1995 Law and Contemporary Problems 130.

31 Tzannes "Legal Ethics Teaching and Practice: Are There Missing Elements?" 19971 TM Cooley Journal of Practical and Clinical Law 59 66; Snyman-Van Deventer and Swanepoel 2017 Obiter 141.

32 Snyman-Van Deventer and Swanepoel 2017 Obiter 140.

33 Burns 1993 Legal Education Review 141; Morgan "Use of the Problem Method for Teaching Legal Ethics" 199839 William and Mary Law Review 409 409; Menkel-Meadow and Sander 1995 Law and Contemporary Problems 130.

34 Burns 1993 Legal Education Review 141141.

35 Ibid. 
(iv) the student's own values, moralities and attitudes, individual responsibility and self-regulation; 36

(v) the student's own decision-making in answering individual questions on the profession and own responsibities and questions on how to commit to the legal profession; ${ }^{37}$

(vi) questions on morals and the legal profession; 38

(vi) the legitimacy of requiring a lawyer to do something in conflict with his or her own personal values;39 and

(vii) the necessity to develop a sense of concern for the public interest and welfare. ${ }^{40}$

In view of the above, the content of a legal ethics module should include more than rote learning. It should include a focus on the development of an understanding of the general theory of ethics as well as the specific legal ethics or responsibilities and ethics of lawyers as governed by the rules of the law societies, the general bar and the Legal Practice Council, and especially the Code of Conduct for All Legal Practitioners, Candidate Legal Practitioners and Juristic Entities. ${ }^{41}$ This should enable students not only to make ethically responsible decisions when practising law, but also in their personal lives. Students should understand theoretical approaches to legal ethics, the purpose, objectives and functions of legal ethics and the rules and principles of legal ethics. A module on legal ethics should further deal with specific practice issues such as admission requirements and the fit-and-proper requirement; codes of conduct; observing the law; professional negligence and professional misconduct; accepted professional practices; prescription of matters; the attorney/client relationship; the best interest of clients; the interest of justice; a legal practitioner's duties to the court; touting and marketing of legal services; honesty and integrity; trust money and financial management; fees and billing; charging for legal services; and the regulatory requirements applicable to attorneys and advocates. It must be emphasised that even though these practice-specific issues will most often form the core of a module on legal ethics, other ethical issues (as already mentioned) should not be seen as less important, but as contributing to the development of a holistic view and sense of legal ethics.

Beca states:

36 Burns 1993 Legal Education Review 141; Menkel-Meadow and Sander 1995 Law and Contemporary Problems 130.

37 Burns 1993 Legal Education Review 141.

38 Menkel-Meadow and Sander 1995 Law and Contemporary Problems 130.

39 Burns 1993 Legal Education Review 141.

40 Menkel-Meadow and Sander 1995 Law and Contemporary Problems 130.

41 Legal Practice Council Notice 198 of 2019. 
"If we want students to be prepared to solve ethical dilemmas, then it is crucial to teach them how to do it. Hence, we need to give them the tools to make a serious discernment and therefore, offer them a method of using those tools." 42

It is thus clear that we have to determine our goal with teaching legal ethics, as well as the content of the legal ethics module in the South African context, before we can determine the method to teach legal ethics. ${ }^{43}$ Kruuse states that the task is rather "to attempt to build students' own capacities for reflective judgment". ${ }^{4}$

\section{Where?}

Not only is it necessary to determine the goals and objectives of teaching legal ethics before it is decided which teaching method to use, but (as mentioned above) it must also be decided whether to teach legal ethics (i) in one standalone ${ }^{45}$ module only; (ii) in a core module and then also include it in other substantive modules; or (iii) throughout the entire curriculum in all substantive modules where applicable or possible, with no specific module dedicated to legal ethics (the so-called pervasive method ${ }^{46}$ or mixed method). In the single/stand-alone module method, legal ethics are taught in one core module, which will include codes of conduct, professional rules and responsibilities, and also the philosophical and ethical issues that give rise to such codes or rules. ${ }^{47}$ If it is decided that legal ethics should be taught in a single module, it is still possible to include aspects thereof in other modules as applicable. Solberg is adamant that legal ethics cannot be taught in one module only and emphasises that it should be included in most modules. ${ }^{48}$ Joy is also of the opinion that it is better to include legal ethics in all modules to ensure that students learn that ethical problems, questions and issues are part of all areas of the practice of law. ${ }^{49}$ Beca states that a legal ethics course (module) "should be also linked to

42 Beca "Teaching Legal Ethics to Law Students: Why, What, How and Who Might Teach?" 20163 Asian Journal of Legal Education 8588.

43 Snyman-Van Deventer and Swanepoel 2017 Obiter 141.

44 Kruuse 2012 Stellenbosch Law Review 280282.

45 Burns 1993 Legal Education Review 151.

46 The pervasive method is the systematic teaching of legal ethics in substantive modules as relevant issues arise and demonstrating that legal ethics are part and parcel of all areas of the law (Burns 1993 Legal Education Review 145). Also see Solberg "Reforming the Legal Ethics Curriculum: A Comment on Edward Rubin's 'What's Wrong With Langdell's Method and What to Do About It"' 200962 Vanderbilt LR En Banc15-16; Henriss-Anderssen 2002 Legal Education Review 53; Menkel-Meadow and Sander 1995 Law and Contemporary Problems 129-138; Egan, Parsi and Ramirez "Comparing Ethics Education in Medicine and Law: Combining the Best of Both Worlds" 200413 Annals of Health Law 303 307-308; Link "The Pervasive Method of Teaching Ethics" 198939 Journal of Legal Education 485 485-489.

47 Burns 1993 Legal Education Review 151.

48 Solberg 2009 Vanderbilt LR 13; Robertson "Providing Ethics Learning Opportunities Throughout the Curriculum" 200912 Legal Ethics 59-76; Joy "Teaching Ethics in the Criminal Law Course" 200448 Saint Louis University LJ 1241.

49 Joy 2004 Saint Louis University LJ 1240-1241; Pierce "Legal Ethics Must Be at the Heart of the Law School Curriculum" 200226 Journal of the Legal Profession 159161. 
other courses, in order to help students build a thinking structure and some content essential to understand ethical issues". 50

Cramton and Martin criticise the pervasive method and state that it "is usually a pretence rather than a reality". ${ }^{51}$ Most lecturers do not devote substantial time in their modules to legal ethics and may even feel uncomfortable dealing with it. ${ }^{52}$ Bundy agrees that lecturers "in mainstream courses would not make a sufficient commitment of classroom time and personal energy to ethics instruction". ${ }^{33}$ He states:

"[T]he pervasive approach suffers from two crippling drawbacks. First, by giving the pieces of legal ethics home everywhere, it effectively deprives its core concepts a home anywhere. Without a required course with significant content, there is no place in which students and instructors confront, in any probing or systematic way the critical ethical concepts, institutional and political understandings, and regulatory alternatives that underlie all areas of professional ethics and regulations."

Cramton and Martin therefore recommend a required course (compulsory module) supported by the inclusion of ethics in specific other modules as agreed by faculty and monitored to ensure effectiveness. ${ }^{55}$ Kelly agrees that the pervasive method is enhanced by also teaching legal ethics in a basic module. ${ }^{56}$ This is supported by Snyman-Van Deventer and Swanepoel and they propose that in the South African context a core module is crucial; students should be taught the skills and processes to identify and solve ethical questions or problems in a core module, but added to this, lecturers should integrate legal ethics in all other core modules. ${ }^{57}$ For example, in a module such as company law, the lecturer can use the topic of fiduciary duties of directors for a discussion on ethics, and can use case law such as Gihwala $v$ Grancy Property Ltd. ${ }^{58}$

However, the success of teaching legal ethics using either the pervasive or the mixed method is dependent on the support of all faculty lecturers and their willingness to incorporate legal ethics into their modules. ${ }^{59}$

50 Beca 2016 Asian Journal of Legal Education 93.

51 Cramton and Martin "Information Technology and Legal Ethics: Expanding the Teaching and Understanding of Legal Ethics Through the Creation of a New Generation of Reference Materials" 1995 Law and Contemporary Problems 337338.

52 Ibid.

53 Bundy "Ethics Education in the First Year: An Experiment" 1995 Law and Contemporary Problems 21.

54 Bundy 1995 Law and Contemporary Problems 33.

55 Cramton and Martin 1995 Law and Contemporary Problems 338.

56 Kelly "Notes on the Teaching of Ethics in Law School" 1980 Journal of the Legal Profession 27.

57 Snyman-Van Deventer and Swanepoel 2017 Obiter 141.

582017 (2) SA 337 (SCA).

59 See Solberg 2009 Vanderbilt LR 15-16; Henriss-Anderssen 2002 Legal Education Review 53; Menkel-Meadow and Sander 1995 Law and Contemporary Problems 129-138; Egan, Parsi and Ramirez 2004 Annals of Health Law 303 307-308; Link 1989 Journal of Legal Education 485 485-489. 


\section{How?}

Only after the faculty has decided on the where and the what of teaching legal ethics can a lecturer decide on the specific teaching method to be used. As stated by Terrel, "one's goal can often determine one's methods". ${ }^{60}$ The teaching method used should not only provide students with knowledge and practical wisdom, but also contribute to the development of practical reasoning skills. ${ }^{61}$ Burns explores seven methodologies ${ }^{62}$ for teaching legal ethics namely, case studies, ${ }^{63}$ problems,${ }^{64}$ Socratic instruction, ${ }^{65}$ discussions, ${ }^{66}$ group work, video and film presentations, ${ }^{67}$ co-curricular (or voluntary) activities ${ }^{68}$ and lectures. ${ }^{69}$ Other methods include the use of social media, such as Facebook, Twitter and Instagram, as well as role play and simulations, law clinics, ${ }^{70}$ written assignments, one-minute essays, games and moot courts. Most of these methods are not exclusive and teaching most often uses a combination of the different methodologies; for example, a video presentation is often followed by a lecture that may also include the Socratic method as well as a class discussion and written assignments. Cramton and Martin submit that students learn in different ways and at different times and therefore a variety of teaching methods should be used. ${ }^{71}$ An integrated approach to teaching legal ethics ensures that students: (i) gain the theoretical and factual knowledge they need; (ii) gain practical wisdom and insight from others, including other students; (iii) learn to understand the links between an ethical dilemma, real life, the law and the implications of it all; (iv) grasp the holistic interplay between ethics and law; and (v) develop necessary practical reasoning skills.

60 Terrell 1995 Law and Contemporary Problems 355355.

61 Jacobowitz and Rogers "Mindful Ethics: A Pedagogical and Practical Approach to Teaching Legal Ethics, Developing Professional Identity, and Encouraging Civility" 20144 St Mary's Journal on Legal Malpractice \& Ethics 198211.

62 Burns 1993 Legal Education Review 151-154. These are also briefly discussed in Snyman-Van Deventer and Swanepoel 2017 Obiter 143-146.

63 Burns 1993 Legal Education Review 151; Snyman-Van Deventer and Swanepoel 2017 Obiter 143-144

64 Burns 1993 Legal Education Review 152; Snyman-Van Deventer and Swanepoel 2017 Obiter 127144.

65 Burns 1993 Legal Education Review 152; Snyman-Van Deventer and Swanepoel 2017 Obiter 144-145.

66 Ibid.

67 Ibid.

68 Burns 1993 Legal Education Review 154; Snyman-Van Deventer and Swanepoel 2017 Obiter 145.

69 Burns 1993 Legal Education Review 152; Snyman-Van Deventer and Swanepoel 2017 Obiter 145-146.

70 For purposes for this article, clinical teaching will not be included as it is not a method to use in a lecture/class.

71 Cramton and Martin 1995 Law and Contemporary Problems 337 338; Kruuse 2012 Stellenbosch Law Review 280 280: "[S]tudents have a range of different learning styles." 
Beca emphasises that from an active-participation paradigm, students must be at the centre of any legal ethics course and activities should be developed based on learning rather than teaching. ${ }^{72}$ Students must develop their own legal reasoning, while acquiring the knowledge they will need in future. ${ }^{73}$ Nicolson advocates interactive teaching methods and he states that it is "more likely to inspire and help students develop their own moral stance and moral reasoning". ${ }^{74}$

\section{Case studies or case discussions ${ }^{75}$}

Blackburn and Niedzwiedz explain that case discussion involves analysis of court opinions most often based on prescribed case law. ${ }^{76}$ Students are encouraged to ask questions, but it works best in smaller classes. ${ }^{77}$ Case discussions in class require that students read the judgment before class and form an understanding of the judgment and, it is hoped, also an own opinion. In class, the students then need to identify the rules of law applicable to the case and analyse its component parts. Through this process, students learn the fundamentals of legal reasoning and the doctrinal rules relevant to the specific case under discussion. ${ }^{78}$ Chang remarks that through reading case law "students learn to identify the same or similar issues in factually different cases, helping them to attain an understanding of judicial thinking". ${ }^{79}$ Chang also explains that there is not necessarily a single correct way of analysing case law and that the process rather than the outcome is important. ${ }^{80}$ Case discussions, rather than a lecture, assist students to perform case analysis and to think critically about the judgment rather than just passively listening to a lecture. ${ }^{81}$

Cramton and Martin use the term "case study" to describe an actual or hypothetical situation featuring important issues of professional ethics in a practice setting that is relevant to the law school course for which it is designed. The case is supported by text, rules, and excerpts that provide what the regular course materials do not - a thorough treatment of the law and ethics of lawyering relevant to the case. The students are placed in the lawyer's position

\footnotetext{
Beca 2016 Asian Journal of Legal Education 89.

Ibid.

Nicolson "Teaching Legal Ethics: What, How and Why" 20101 Education and Law Review 110.

75 Althougn there is a certain focus in the USA on the use of case books, most lecturers in South Africa prefer to select the case law they prescribe in accordance with their own opinion of the value of specific judgments.

76 Blackburn and Niedzwiedz "Do Teaching Methods Matter? A Field Study of an Integrative Teaching Technique" 1981 American Business Law Journal 525525.

77 Ibid.

78 Chang "The Teaching of Law in the United States: Studies on the Case and Socratic Methods in Comparison With Traditional Taiwanese Pedagogy" 20094 National Taiwan University Law Review 113.

79 Chang 2009 National Taiwan University Law Review 5.

80 Chang 2009 National Taiwan University Law Review 13.

81 Ibid.
} 
of considering the alternative courses of action available, which forces an evaluation of the consequences of the possible paths. ${ }^{82}$

Brest explains that the case-study method teaches students problem-solving skills through the following question: "Given this set of facts and these precedents, what are the rights and liabilities of the parties?"83 The answer to this question provides the foundation needed by the lawyer to advise his/her client about the legal consequences of his/her course of action. ${ }^{84} \mathrm{~A}$ case study illustrates how a particular situation is dealt with through the analysis of actual cases of misconduct. Students learn from these real-life legal ethical problems how to apply the relevant law, codes of conduct or professional rules. ${ }^{85}$ However, Brest criticises the case-study method, because it is limited by the specific facts of particular appellate cases prescribed and thus provides only static situations with those specific facts whereas lawyers are faced by changing situations in everyday practice. ${ }^{86}$ Burns agrees that when using the case-study method, students do not develop skills to recognise or identify ethical dilemmas as they arise. ${ }^{87} \mathrm{He}$ describes case studies as a useful secondary source that provide the student with insight into the disciplinary processes as well as the sanctions to be imposed for a breach of codes of conduct or professional rules. ${ }^{88}$ However, the case-study method can be expanded by inclusion of "what if" scenarios. The lecturer can use the original case study and then add further questions based on an additional "what if" scenario.

Chang agrees with Brest that the case-study method limits the students to a specific set of facts and does not provide for the complexity of the legal process. ${ }^{89} \mathrm{He}$ offers a further critique of the case-study method, ${ }^{90}$ namely: (i) problems exist with case books; 91 (ii) the case-study method encourages students to view law in an incomplete conception; ${ }^{92}$ (iii) the case-study method omits the fact-finding and the legal process;93 and (iv) the case-study method fails to teach lawyering. ${ }^{94}$

However, Chang also lists a number of arguments in support of the casestudy method ${ }^{95}$ - namely: (i) interest in learning increases; (ii) students are

\footnotetext{
Cramton and Martin 1995 Law and Contemporary Problems 340.

Brest 1995 Law and Contemporary Problems 57.

Ibid.

Burns 1993 Legal Education Review 151.

Brest 1995 Law and Contemporary Problems 7.

Burns 1993 Legal Education Review 152.

Ibid.

Chang 2009 National Taiwan University Law Review 18.

Chang 2009 National Taiwan University Law Review 16-19.

Chang 2009 National Taiwan University Law Review 16-17.

Chang 2009 National Taiwan University Law Review 17.

Chang 2009 National Taiwan University Law Review 17-18.

Chang 2009 National Taiwan University Law Review 18-19.

95 Chang 2009 National Taiwan University Law Review 13-16.
} 
taught how to read cases; ${ }^{96}$ (iii) students are taught how to think like lawyers; 97 (iv) the law is learnt through a series of precedents; (v) students develop an understanding of the legal process; (vi) it cultivates moral imagination;98 and (vii) it develops mental toughness. ${ }^{99}$ In using the case-study method or case discussions when teaching legal ethics, all the arguments in support of the casestudy method can be viewed as positive results of using this method. It especially contributes to students realising that they need to consider different opinions and perspectives. They learn how rules and doctrines are applied, but also that after analysis of the law and the circumstances, judges may exercise discretion in reaching a decision. ${ }^{100}$ Students learn to recognise the important facts, and to identify the court's decision and reasoning. ${ }^{101}$ It gives students the opportunity to examine the extent to which a judge not only follows the law and also precedents, but also why and how a judge avoids precedents. ${ }^{102}$ In discussing a specific judgment, the lecturer can guide students to the relevant and important facts and circumstances that lead to or cause an ethical dilemma and also to the applicable law, whether rules or legislation. Students must then identify the decision of the court and its reasoning. But students should also be allowed to explore critically different views on the decision and form their own opinion, and they should even be allowed to propose their own solutions to the specific ethical problem. Parks notes that the case-study method involves more than just listening as in a lecture but requires participation; the method enables students to learn from the experience and insights of other students and the lecturer. ${ }^{103}$

For example, in using the facts and judgment of Jiba $v$ General Council of the Bar of South Africa, ${ }^{104}$ the focus can be placed on the relationship between a legal practitioner and the court. Students can discuss the facts and identify specific complaints against the appellant. Students can also be asked to identify and evaluate the appropriate sanctions and the order made by the court. Students could then use this judgment as a basis for compiling a list of conduct that indicates that a person is not a fit and proper person to practise as a legal practitioner.

Cramton and Martin believe that the use of case studies makes it possible to incorporate legal ethics in most modules. ${ }^{105}$ It is important to emphasise the role of the lecturer in the case-study method. The lecturer must play an active part in

96 Chang 2009 National Taiwan University Law Review 13.

97 Chang 2009 National Taiwan University Law Review 14.

98 Chang 2009 National Taiwan University Law Review 15.

99 Chang 2009 National Taiwan University Law Review 16.

100 Chang 2009 National Taiwan University Law Review 15.

101 Chang 2009 National Taiwan University Law Review 14.

102 Chang 2009 National Taiwan University Law Review 15.

103 Parks "Appropriate Methods for the Teaching of Legal Skills in Practical Training Courses" 1990 8(2) Journal of Professional Legal Education 161170.

1042019 (1) SA 130 (SCA) 130.

105 Cramton and Martin 1995 Law and Contemporary Problems 341. 
analysing the ethical problems in the case law and ensure that students develop insight into what is emphasised or ignored in order to shape their perception of what constitutes an ethical lawyer. ${ }^{106}$ According to Joy, the lecturer can use case law effectively if he/she guides the students through the judgment and also uses additional material, specific assignments, and requires students to take part in class or smaller group discussions. ${ }^{107}$ Journal articles dealing with case discussions provide additional material that the lecturer can use in the casestudy method. ${ }^{108}$

It should be noted that the use of judgments should not be limited to case studies or case discussions, but can also be used in the other teaching methods.

\section{Problems ${ }^{109}$}

Brest prefers transactional case studies to case studies of (for example) appellate decisions. ${ }^{110}$ However, in analysing his transactional case studies, they prove to be just a variation on the problem method. The starting point of the problem method is a factual situation - in other words, the problem that the student needs to solve. ${ }^{111}$ The problem thus is the stimulus and reason for learning. Students should view legal ethics as part of their everyday life, but especially as part of what they will deal with as legal practitioners. Students must therefore be able to see themselves in the role of the attorney or advocate making ethics decisions. This is best achieved by using the problem method as it places the student hypothetically in the role of the lawyer. ${ }^{112}$ Morgan explains that the problem method, like the case-study method, gives legal issues a human face. ${ }^{113}$

When using the problem method, the lecturer gives the students a specific hypothetical problem that a lawyer may face in practice - for example, a lawyer receives incriminating documents from his client that also indicate certain crimes that will be committed in the near future. Questions pertaining to the problem can be asked by the lecturer, such as: what must you as the lawyer do with the

106 Joy 2004 Saint Louis University Law Journal 1243.

107 Joy 2004 Saint Louis University Law Journal 1245.

108 In this regard, a very useful article is Van Eck "Ethical and Professional Duties in the Use of Recycled Legal Instruments: A Trio of Cases" 20202 Journal of South African Law 354-368 where she discusses three judgments, namely Cele $v$ The South African Social Security Agency 2008 (7) BCLR 734 (D); Sibiya v Director-General: Home Affairs 2009 (3) All SA 68 (KNP); Tekalign v Minister of Home Affairs 2018 (3) All SA 291 (ECP).

109 For a detailed discussion of the use of the problem method, see Morgan 1998 William and Mary Law Review 409-419.

110 Brest 1995 Law and Contemporary Problems 57.

111 Martin "Teaching Legal Problem Solving: A Problem-Based Learning Approach Combined With a Computerised Generic Problem" 200414 Legal Education Review 7778.

112 Morgan 1998 William and Mary Law Review 417; Tzannes 1997 TM Cooley Journal of Practical and Clinical Law 62.

113 Morgan 1998 William and Mary Law Review 417. 
documents; should you give it back to your client; and/or should you inform the authorities? Students can discuss the problems and related questions in class, or individual assignments can also be given and students must then hand in their own written answer to the problem. In determining the solution to ethical problems or questions, students need to identify the issues by using their knowledge of ethical and moral standards and the applicable laws, case law, codes of conduct or professional rules. ${ }^{114}$

The problem method requires students to identify the issues from the facts and thus necessitates that they engage with the facts more intensely. With the problem method, students themselves must determine the ethical issues and find a solution. ${ }^{115}$ The problem method requires students to think about the law and ethics while applying cases, statutes, codes and other legal material to solve the hypothetical problem. ${ }^{116}$ Morgan states that using problems helps students learn how to integrate the requirements of the law and their conscience. ${ }^{117}$ Through using the problem method, students develop decisionmaking skills and problem-solving skills. ${ }^{118}$ In solving the problem, students need to go through the various stages of problem-solving and, in the process, they also acquire substantive contextualised knowledge. ${ }^{119}$

The problem method can be linked to case studies, as a lecturer may use a set of facts from a judgment and pose it as the problem for the class to solve. Again it is important to emphasise that all the teaching methods can and should be used in support of the teaching and learning experience of the students and one method does not exclude the use of other methods.

\section{Socratic method}

Bateman states that the goal of the Socratic method is to develop higher thinking skills, problem-solving skills, reflective thinking and logical reasoning. ${ }^{120}$ $\mathrm{He}$ concludes that these skills "enable the student to draw reasonable inferences, recognize assumptions, think deductively, interpret various points of view, and evaluate arguments". ${ }^{121}$ These skills also serve the student well in solving an ethical problem. Tzannes describes the Socratic method as a process of hypothesis elimination, finding better hypotheses by steadily identifying and eliminating those that lead to contradictions. ${ }^{122}$ Through the asking of questions and using the students' answers in guiding the conversation, the lecturer can

114 Burns 1993 Legal Education Review 152; Morgan 1998 William and Mary Law Review 409.

115 Burns 1993 Legal Education Review 152.

116 Morgan 1998 William and Mary Law Review 414.

117 Morgan 1998 William and Mary Law Review 417.

118 Martin 2004 Legal Education Review 79.

119 Ibid.

120 Bateman "Toward Diversity in Teaching Methods in Law Schools: Five Suggestions From the Back Row" 199717 Quinnipiac Law Review 397401.

121 Bateman 1997 Quinnipiac Law Review 402.

122 Tzannes 1997 TM Cooley Journal of Practical and Clinical Law 63. 
place emphasis on specific ethics issues. The lecturer can, for example, use prescribed material to ask questions on: the sources of ethical duties; the "fit and proper" requirement; touting; the balance between the best interest of clients and the administration of justice and the duty to the court; the standard of conduct expected of legal practitioners, specifically honesty and integrity; ${ }^{123}$ accepting clashing briefs; 124 failing to prepare properly and fully to represent a client; ${ }^{125}$ and failure to act in the best interest of a client. ${ }^{126}$ In the conversation and the specific questions asked, the lecturer can focus on decided cases, ethical problems and even hypothetical problems. Through the conversation, the students come to understand the nuances of the ethical problem and are able to formulate an ethical stance on the issue under discussion. ${ }^{127}$ However, it is necessary that the lecturer ensures that all students feel safe and secure to enable them to freely engage in the conversation. ${ }^{128}$ Bateman suggests that the lecturer should take care to call on students by name to answer questions rather than ask for volunteers. ${ }^{129}$ This is to ensure that students stay alert and prepare to participate. ${ }^{130}$ In using a hypothetical problem or a real case, the lecturer can lead students through the ethical issues at hand by asking specific questions to develop a sense of ethical problems and the way to resolve them.

The Socratic method can also be used with case studies or the problem method. The Socratic method enables the lecturer "to guide the student toward an articulation of ideas expressed in the case".131 The lecturer can ask questions on the case law prescribed or the problem posed in such a way as to contribute to the enhancement of the specific ideas or outcomes the lecturer identified as important. It enables the lecturer to focus on a specific ethical problem or question and to assist the students in finding solutions to ethical problems. For example, using Jiba $v$ General Council of the Bar of South Africa, ${ }^{132}$ the lecturer can start with the seven specific complaints ${ }^{133}$ against the appellant and guide students through the majority and minority judgments and the different interpretations of the judges pertaining to the issue of misconduct by the parties involved. The lecturer can ask questions on whether students perceive the parties to be unreliable, dishonest, incompetent or unsuitable. The high standard of integrity expected of legal practitioners and the determination of whether a person is fit and proper can also be discussed.

123 Most of these aspects are dealt with in Van Eck 2020 Journal of South African Law 354-368.

124 General Council of the Bar of South Africa v Matthys 2002 (5) SA 1 (E).

125 Ibid.

126 Ibid.

127 Tzannes 1997 TM Cooley Journal of Practical and Clinical Law 63.

128 Burns 1993 Legal Education Review 152.

129 Bateman 1997 Quinnipiac Law Review 414. From own experience and that of colleagues, we have concluded that owing to cultural differences and other perceptions of students in a South African context, the lecturer should rather ask the whole class or call on several students.

130 Bateman 1997 Quinnipiac Law Review 414.

131 Chang 2009 National Taiwan University Law Review 5 and see also 27.

132 Supra.

133 Jiba v General Council of the Bar of South Africa supra 136-137. 


\section{Discussions}

Lecturers can use discussions with almost all other teaching methods. It is an integral part of the case discussion in the case-study method, but discussions need not focus on case law only. The discussion can focus on different ethical dilemmas that do not necessarily originate in case law. Ideally, discussions should be used in smaller groups where students can engage personally with ethical and moral dilemmas. Students also learn the value of discussion in problem-solving. ${ }^{134}$ The lecturer plays an important role as facilitator of the discussion and should take care to lead the discussion in such a way as to ensure that students indeed engage with the issues and are able to identify the problems and through the discussion find their own solution to the ethical dilemma. The class discussion should encourage students to participate and to prepare for class. Discussions would encourage the student to engage with the prescribed material before class, but also during class when participating in the discussion or even when only listening to the discussion. Through discussions, students are also exposed to other points of view and intrepretations; by sharing views, students gain better perspectives on the ethical and moral dilemma under discussion. The class discussion can also focus on prescribed material other than case law. In this regard, as an example, the article of Van Eck ${ }^{135}$ can be used to focus on different issues for discussion in class, such as criteria for a fit and proper person; ${ }^{136}$ ethical and professional duties; ${ }^{137}$ fees and billing ${ }^{138}$ and overreaching fees; ${ }^{139}$ misleading the court; ${ }^{140}$ the duty to inform the court; ${ }^{141}$ commissioner of oaths and the process of attestation; ${ }^{142}$ and touting. ${ }^{143}$

\section{Group work}

Group work can be closely linked to discussions. While group work may include other forms of collaboration, such as group assignments, group work is an important tool to use to ensure individual participation in activities, especially discussions. ${ }^{144}$ It may be easier for some students to participate in a smaller group discussion than in a bigger class discussion. Beca explains that students should be asked to work in permanent groups where they can engage in discussions on difficult issues raised in class. In smaller groups, students can

134 Burns 1993 Legal Education Review 153.

135 Van Eck 2020 Journal of South African Law 354-368.

136 Van Eck 2020 Journal of South African Law 358-359.

137 Van Eck 2020 Journal of South African Law 359-360.

138 Van Eck 2020 Journal of South African Law 360-362.

139 Van Eck 2020 Journal of South African Law 364-366.

140 Van Eck 2020 Journal of South African Law 362.

141 Van Eck 2020 Journal of South African Law 363-364.

142 Van Eck 2020 Journal of South African Law 362-363.

143 Van Eck 2020 Journal of South African Law 361-362.

144 The article of Van Eck (and all the issues identified there) again serves as an example of a source of discussion topics as well as case discussions. 
cooperate and try to understand others' point of view while also putting forward their own points of view, moral position and ethical reasoning. ${ }^{145}$ Group work can also be used with other methods and is ideal to use for reflection after video and film presentations or simulations. Group work, whether in the form of written or group discussions, can focus on a specific issue - for example, the concept of a "fit and proper person to practise as a legal practitioner" - and then each group can deal with a specific judgment. In feedback to the whole class, each group gives feedback on their judgment and the class can then list specific requirements or practices that will determine whether or not a person is fit and proper. ${ }^{146}$

\section{Video and film presentations}

Tzannes explains that films and videos can raise ethical issues and problems to engage students both emotionally and intellectually. ${ }^{147}$ They also stimulate interest and attention. Students tend to understand concepts better through images. However, it is quite often difficult to find suitable material and it may be expensive. ${ }^{148}$ Platforms such as YouTube may offer suitable clips. When using film and television in class, it should always include a reflection on the conduct of the fictional character and the situation. This should also lead students to question and reflect on their own values. ${ }^{149}$ It is necessary to ensure that the ethical issue is identified and that students are guided through their prescribed material to assist them in formulating a solution to the problem posed in the video or film presentation. The reflection on the video or film presentation can take various forms and can, for example, include a class discussion, a written assignment or a lecture on the issues identified in the video or film.

\section{Voluntary (co-curricular) learning activities}

Voluntary learning opportunities are extra opportunities students can use to enhance their studies. They are not part of the compulsory lectures and do not form part of the formal curriculum. Co-curricular activities are thus voluntary learning opportunities and should serve to reinforce legal ethical issues already raised. ${ }^{150}$ Different activities can be used - for example, guest lectures on ethical issues by judges, lawyers (practising attorneys and advocates), lawyers in the financial services industry and in the insurance industry or even from the banking sector; panel discussions with invited guests such as judges and/or

145 Beca 2016 Asian Journal of Legal Education 89.

146 Jiba v General Council of the Bar of South Africa supra; Jasat v Natal Law Society 2000 (3) SA 44 (SCA); General Council of the Bar of South Africa v Matthys supra; Society of Advocates of Natal v Merret 1997 (4) SA 374 (N).

147 Tzannes 1997 TM Cooley Journal of Practical and Clinical Law 63.

148 Burns 1993 Legal Education Review 154.

149 Rhode "Legal Ethics: Prime Time and Real Time" 20121 Berkeley Journal of Entertainment and Sports Law 113113.

150 Burns 1993 Legal Education Review 154. 
practitioners; study groups or tutor groups;151 moot courts;152 and the use of social media. ${ }^{153}$ Through guest lecturers, students are afforded the opportunity to interact with professionals and to hear about "real-life" experiences relating to ethical dilemmas.

\section{Lectures}

Lectures are cost-effective and require less input than, for example, the development of a video. However, a very specific input is still required from the lecturer to determine the knowledge students are expected to gain from a lecture; and input from the student is also required as they should prepare before class and study the prescribed material. ${ }^{154}$ The lecturer must also decide on the content and may include case law and other materials. Tzannes observes that lectures do not require active student involvement, but can still be used to teach primary information. ${ }^{155}$ Burns mentions that criticism against the lecture method includes that it is more suitable for teaching black-letter ethics law ${ }^{156}$ and does not assist in developing analytical abilities. ${ }^{157}$ Using formal lectures, legal ethics can be included in other modules and Joy advises that an ethical problem can be raised during a lecture, such as by asking, in a criminal law lecture, "Could you defend this guilty client?". ${ }^{158}$ Although lectures are not ideal from a paradigm of active participation, lecturers can use them to explain ideas, principles and rules - for example, by applying the theory or factual information to concrete situations. In other words, the lecturer can explain the theoretical aspects with examples. ${ }^{159}$ A lecture can start with a reference to case law or an article $^{160}$ and link this to the primary information that will be taught in the specific lecture.

\section{Social media, electronic media and the Internet}

Students actively use social media and are used to immediate answers, communication and information. They use various social media platforms to communicate and to get information. They are used to fast responses on their postings and are equally quick to respond to those of others. They most

151 Burns 1993 Legal Education Review 154.

152 Moot courts are discussed below as a separate method of teaching and learning.

153 Hemingway "Keeping It Real: Using Facebook Posts to Teach Professional Responsibility and Professionalism" 201343 New Mexico Law Review 4356.

154 See Beca 2016 Asian Journal of Legal Education 90.

155 Tzannes 1997 TM Cooley Journal of Practical and Clinical Law 5962.

156 The focus will be on theory, principles from legislation, regulations and codes, case law, textbooks and not skills.

157 Burns 1993 Legal Education Review 154.

158 Joy 2004 Saint Louis University Law Journal 1239-1248.

159 See Beca 2016 Asian Journal of Legal Education 90.

160 Van Eck 2020 Journal of South African Law 354; Slabbert "The Requirement of Being a 'Fit and Proper' Person for the Legal Profession” 2011 Potchefstroom Electronic Law Journal 209. 
probably use the Internet on a daily basis and are familiar with different social media platforms such as Facebook, Instagram, Twitter, Snapchat and WhatsApp, as well as Internet pages, blogs and search engines. The lecturer can thus use students' facility with social media and the Internet as a learning tool to capture their attention and awareness ${ }^{161}$ and include social media in the module.

At the University of the Free State, Blackboard is used and is an ideal platform to facilitate both formal discussions, as set and moderated by the lecturer, and informal dicussions or chats between the students. A lecturer can use Blackboard or any of the social media platforms to teach legal ethics through both the problem and discussion methods by communicating an ethical problem and ensuring student participation in the on-line discussion of the problem. ${ }^{162}$

The advantages of using technology are explained by Anthon, Hemingway and Smith. ${ }^{163}$ They contend that most students are familiar with Facebook (and now also Instagram, Snapchat and others) and may even use them more than email. ${ }^{164}$ Just like in the USA, South African law students also get law-schoolrelated information via Facebook pages of both the law school and student organisations. ${ }^{165}$ A lecturer can use a Facebook group to send different types of messages to the whole class. The post can be a simple message; a message with a file or a link to specific Internet sites; or even videos and photos. ${ }^{166}$ The messages can, for example, be a follow-up on a class discussion ${ }^{167}$ or a lecturer can use posts to illustrate ethical dilemmas. ${ }^{168}$ Students can reply to the posts and a Facebook group can also facilitate a group/class discussion. ${ }^{169}$ Students can also ask questions or post relevant information on the group; ${ }^{170}$ to encourage participation, students may also contribute anonymously.

Snyman-Van Deventer and Swanepoel comment:

"Posts on social media can place emphasis on specific ethical issues to enhance or add to aspects dealt with in, for example, a lecture. Alternatively, social media can be used in a more focused way to deal with specific aspects or issues." 171

161 Snyman-Van Deventer and Swanepoel 2017 Obiter 146.

162 Ibid.

163 Anthon, Hemingway and Smith "A Technological Trifecta: Using Videos, Playlists, and Facebook in Law School Classes to Reach Today's Students" 2014 Rutgers Computer \& Technology Law Journal 1 1-16.

164 Anthon, Hemingway and Smith 2014 Rutgers Computer \& Technology Law Journal 7.

165 Ibid.

166 Anthon, Hemingway and Smith 2014 Rutgers Computer \& Technology Law Journal 8.

167 Ibid.

168 Hemingway 2013 New Mexico Law Review 43-45.

169 Anthon, Hemingway and Smith 2014 Rutgers Computer \& Technology Law Journal 9.

170 Ibid.

171 Snyman-Van Deventer and Swanepoel 2017 Obiter 146. 


\section{Role-play, mock trials and simulations ${ }^{172}$}

Role-play, mock trials and simulations do share certain qualities with clinical learning. ${ }^{173}$ Teaching legal ethics through simulations involves role-play in a simulated practice setting where students play the role of the client, the lawyer, or even the judge or members of disciplinary boards, ${ }^{174}$ as well as witnesses and clients. ${ }^{175}$ Nicolson explains that role-play and simulations will contribute to the development of moral sensitivity and judgement, because it is more likely to engage the interest and emotions of students and their experience will thus be more personal, immediate and realistic. ${ }^{176}$ It is an especially useful teaching tool if students are encouraged to see issues from the other side. ${ }^{177}$ Burns states that format, organisation, personnel, material and manner of class presentation are very important in the planning of a successful legal ethics teaching programme. ${ }^{178} \mathrm{He}$ warns that using the simulation method requires a higher level of planning and administration than, for example, the case-study method. ${ }^{179}$ Bundy emphasises that role-play as a teaching method places extraordinary demands on the time and energy of lecturers. ${ }^{180}$ It is important to note that, just as in the case with video and film presentations, students should be given the opportunity to reflect on the simulation and on how to solve the ethical dilemma or address the ethical issue raised. ${ }^{181}$

\section{Written assignments}

Written assignments can be used to develop not only writing and research skills but also how to deal with specific topics in legal ethics. Legal-writing exercises can be used to expose students to ethics. ${ }^{182}$ As written assignments can take many forms and vary in length and structure, it is possible to use assignments to focus specifically on legal ethics and to cover different topics on legal ethics. Students may be asked to write essays, opinions, briefs or memoranda. For example, students could write an essay on the difference between ethics and

172 For a discussion of the use of role play and simulation at a USA law school, see Bundy 1995 Law and Contemporary Problems 19, as well as Kruuse 2012 Stellenbosch Law Review 280 289-295.

173 Tzannes 1997 TM Cooley Journal of Practical and Clinical Law 63-64.

174 Ibid.

175 Burns "Teaching the Basic Ethics Class Through Simulation: The Northwestern Program in Advocacy and Professionalism" 199558 Law and Contemporary Problems 3741.

176 Nicolson 2010 Education and Law Review 10.

177 lbid.

178 Burns 1995 Law and Contemporary Problems 39.

179 Burns 1995 Law and Contemporary Problems 40.

180 Bundy 1995 Law and Contemporary Problems 1927.

181 See Beca 2016 Asian Journal of Legal Education 90.

182 Weresh "Fostering a Respect for Our Students, Our Specialty, and the Legal Profession: Introducing Ethics and Professionalism into the Legal Writing Curriculum" 200521 Touro Law Review 427440. 
morality. The brief could, for example, be on a judgment involving ethical issues that is on appeal. Students could also write opinions for a client - for example, on the behaviour of an attorney who had supposedly mishandled trust funds causing the client to suffer damages. Students could also write a brief on the guidelines provided by courts on the high standard of integrity expected of legal practitioners and the determination of a person as fit and proper to practise as a legal practitioner. Linked to this, students could also write on the professional and ethical duties involved in providing services as a legal practitioner. A written assignment could, for example, be given to students to comment on the role of the legal practitioner in ensuring the right to a fair trial and to prevent substantial injustice with reference to Mackay $v$ Legal Aid Board. ${ }^{183}$ Bateman observes that concrete feedback on written assignments is crucial. ${ }^{184} \mathrm{He}$ also recommends that written assignments be viewed as teaching tools rather than as assessment or grading tools. ${ }^{185}$

\section{One- (or five-) minute essays}

The one-minute essay is based on a focused question that can be answered within a minute (or a few minutes) and the answer is based on the student's knowledge or opinion. ${ }^{186}$ Although the one-minute essay is mostly used to ascertain the students' understanding of the lecture and particularly what they do not understand, ${ }^{187}$ it can be used to focus the attention of the students on specific ethical issues. The one-minute essay can also be used to ascertain students' understanding of case law and the ethical issues in judgments.

The one-minute essay can be adapted to ensure classroom participation. The one-minute essay ensures participation of all students, even the less vocal ones. It also provides students with the opportunity to offer their own opinions on the question asked. The lecturer can build on this and move to key concepts and principles and more difficult questions. Through the questions posed in the oneminute essays, the lecturer can focus the students' attention on the important aspects of the lecture and guide them to their study material.

\section{Games}

Bateman declares that "introducing games into the classroom can increase student cooperation, motivation, and may improve doctrinal learning". ${ }^{188}$ Through adapting popular television gameshows for the classroom, students will

183 Bateman 1997 Quinnipiac Law Review 416.

184 Mackay $v$ Legal Aid Board 2003 (1) SA 271 (SE).

185 Mackay $v$ Legal Aid Board supra 418.

186 On Course "One-Minute Paper" https://oncourseworkshop.com/self-awareness/one-minutepaper/ (accessed 2021-02-04).

187 Holtzman "Adapting the One-Minute Paper for Active Learning" 2007 Academic Exchange Quarterly https://wsac.wa.gov/sites/default/files/2014.ptw.\%285\%29.pdf (accessed 2020-02-25).

188 Holtzman 2007 Academic Exchange Quarterly 419. 
understand the rules of the game and participate more freely. However, the game should never trivialise the ethical issues. It is best suited to teach principles and rules. There are different games that can be used to teach the theory and principles. For example, a lecturer can use a beach ball to ensure that students participate in class discussions. Asking a question on an ethical issue, the lecturer throws the ball into the class and the student who catches the ball is required to answer the question, and in that way the discussion starts. A game like "Who Wants to Be a Millionaire?" can be used to review case law. Other games such as "30 seconds" can also be used to teach theory and principles. Another method to ensure that students read the prescribed case law and to deal with legal ethical issues dealt with in the case law, is to put typed paragraphs from judgments into balloons. This method can also be used to facilitate discussion using specific quotations from case law - for example, "The importance of legal practitioners being scrupulously honest in their dealings with the court has been stressed time and again in this country"; 189 "The attorney's profession is an honourable profession, which demands complete honesty and integrity from its members"; 190 "A client is entitled to taxation of his or her attorney's account". ${ }^{191}$ The balloons are tossed around by the students until they burst, leaving the student with the burst balloon to identify the relevant judgment and discuss the ethical issue identified in the paragraphs.

\section{Moot courts}

Although moot courts are mostly a co-curricular learning activity, they can be incorporated in a specific module to teach legal ethics. It is necessary for a school or faculty to decide whether to do a smaller moot in a specific module, or to facilitate a moot court on legal ethics as a co-curricular activity. A moot court is explained as follows:

"A moot court competition simulates a court hearing (usually an appeal against a final decision), in which participants analyse a problem, research the relevant law, prepare written submissions, and present oral argument. Moot problems are typically set in areas of law that are unsettled or that have been subject to recent developments. They usually involve two grounds of appeal, argued by each side." 192

Ethical problems can be used to design a set of facts for a moot court. Through the use of moot courts, students are not only challenged to solve the ethical problem on behalf of their client, but also develop their advocacy skills. In a moot, students must submit written submissions or memoranda, and then must present their client's case in an oral presentation before the judge. The students

189 Jiba $v$ General Council of the Bar of South Africa supra 149.

190 Summerley $v$ Law Society, Northern Provinces 2006 (5) SA 613 (SCA).

191 Blakes Maphanga Inc v Outsurance Co Ltd 2010 (4) SA 232 (SCA) 240.

192 University of Oxford: Faculty of Law "Mooting: What Is It and Why Take Part?" https://www.law.ox.ac.uk/current-students/mooting-oxford/mooting-what-it-and-why-take-part (accessed 2020-03-02). 
develop their legal research and writing skills and learn to work in a team. The moot court stimulates critical thinking and forces students to engage with the subject matter, materials and the legal ethics issue. It also encourages preparation and participation. Using moot courts requires a huge input from the lecturer and should be a project of school or faculty rather than being used in a module on legal ethics where it is the responsibility of a single lecturer. The number of skills developed through an ethics moot justifies the school or faculty in taking responsibility for moot courts on legal ethics. Law schools or faculties with a vibrant and active moot court culture may be able to introduce a moot on ethics in addition to other moot court activities. But even if a law school is not actively involved in moot courts or moot competitions, a moot on legal ethics will add to the more practical experience of students.

The purpose of setting out all the various methods of teaching ethics has not been clearly explained or summed up.

\section{CONCLUSION}

The "how" question should be answered by the lecturer teaching legal ethics and it is not necessary to choose just one teaching method, especially when most methods cannot be used in isolation. It is clear that, in teaching legal ethics, it is preferable for a combination of the methodologies as described above to be used; this will contribute to better teaching and learning within any legal ethics module or other modules that may include the teaching of legal ethics. Exposure to legal ethics in various ways contributes not only to the development of the ability to identify legal ethical problems, and of the skills to solve such problems, but also to the understanding that ethics form part of the working environment of every lawyer; furthermore, it forms part of everyday life. Students will also develop an understanding that everybody has a responsibility for his or her own ethical behaviour and the decisions made on a daily basis.

Snyman and Swanepoel have concluded:

"In designing a legal ethics module for the South African LLB student, ethics must be seen as more than just legal rules or obligations. It is not only about proper behaviour, but also about responsibility, integrity, honesty and trustworthiness, inspired and guided by personal values, religion, philosophy as well as professional rules of conduct and codes of ethics. For the South African LLB student, a stand-alone module on legal ethics is indeed crucial. This should however be followed by the inclusion or enforcement of legal ethics in other modules also." 193

\section{Brest states it best:}

"Indeed, in the end, no law school curriculum can substitute for good mentoring in a lawyer's early years of practice and for the experience of grappling with actual problems day to day. But law schools can provide a strong foundation for the

193 Snyman-Van Deventer and Swanepoel 2017 Obiter 147. 
ongoing, reflective self-education that is integral to any successful professional career." 194

By including a core module on legal ethics and also focusing on ethical issues in other modules, we can contribute to the development of an ethical culture in law students as prospective lawyers. The content of the module of legal ethics and the method of teaching legal ethics should contribute to an understanding of the duties and responsibilities of a lawyer and guide the student in developing his/her own moral compass. In answering the what, where and how questions, we can plan, structure and develop a module on legal ethics that will enable students to develop the necessary skills of problem-solving, decision-making and practical judgment in line with the duties and responsibilities of an ethical lawyer.

194 Brest 1995 Law and Contemporary Problems 57. 